\title{
Generating Constitutional Meaning
}

\author{
Larry Kramer $\dagger$
}

Reva Siegel's lecture reflects and is part of a seismic shift in constitutional theory that has been taking place over the past decade or so, a shift away from how legal scholars have theorized about the Constitution since Brown v. Board of Education. ${ }^{1}$ Brown was a signal event in constitutional law, and it begat a cottage industry as a remarkable number of the nation's best legal minds turned their attention to developing general theories about how to read the Constitution. ${ }^{2}$ Largely taken for granted in this post-Brown debate was the question that had preoccupied constitutional discourse for the two centuries before Brown: who should interpret the Constitution? Through most of American history, constitutional controversy had centered around the locus of interpretive authority. There was a general consensus about how the Constitution should be interpreted, a conventional form of legal analysis that mixed arguments based on text, history, precedent, and policy. Given the elasticity of this method, disagreement centered on which institution or institutions had power to interpret: Congress, the President, the courts, the states, or the community at large.

After Brown, combatants on both sides came to accept the judiciary as the authoritative interpreter of the Constitution (with the Supreme Court as final arbiter of constitutional meaning), and debate shifted to the question of interpretive methodology. There was profound disagreement about where the Constitution ended and politics began, as well as a broad range of views about how to read the text. But that constitutional law was first and foremost a matter for judges became an accepted norm across the legal and political spectrum. This shared assumption, in turn, had profound consequences for the kinds of theories that developed, consequences that went largely unnoticed precisely because what was at issue on all sides was how judges should interpret the text, not whether they should do so.

The two most important characteristics of this post-Brown scholarship, which defined constitutional law for nearly two generations, were, first, that it was almost wholly normative in content, and second, that it

Copyright $(\mathcal{C} 2006$ California Law Review, Inc. California Law Review, Inc. (CLR) is a California nonprofit corporation. CLR and the authors are solely responsible for the content of their publications.

+ Richard A. Lang Professor and Dean, Stanford Law School.

1. 347 U.S. 483 (1954).

2. Barry Friedman, The Birth of an Academic Obsession: The History of the Countermajoritarian Difficulty, Part Five, 112 YALE L.J. 153 (2002). 
was written from the perspective of a judge called upon to decide a case. There was little or no concern for external or endogenous influences on the shape of constitutional law, and equally little emphasis on the sorts of analyses we associate today with scholars working in law and society. Constitutional theorists did not necessarily deny that there were such influences. They were, rather, indifferent to them, focused entirely on what a judge ought to do in deciding a constitutional case. And, as Siegel suggests several times in her lecture, this focus led constitutional scholarship to overlook some significant forces shaping the law.

Siegel's lecture is part of an academic movement that urges us to look at actors other than judges and also believes that one cannot understand how norms of constitutional law develop and become established without attending to audiences beyond the professional one. As of today, 1 am sorry to report, this new focus remains on the fringes of constitutional theory. Conventional constitutional scholars increasingly find themselves forced to respond and react to work in this vein, but the Court-centeredness of the legal profession is so deep and so taken for granted that the movement of which Siegel is a central player can still be marginalized as "the Constitution Outside the Courts"3-as if this were an exceptional and highly peculiar thing to contemplate.

Although some scholars interested in popular constitutionalism (including Siegel in other work ${ }^{4}$ ) have pursued a normative agenda, ${ }^{5}$ Siegel says her objective in today's lecture is merely descriptive: she wants to offer a positive account of (part of) the process by which constitutional norms are shaped and reshaped in the community, a process that succeeds because it preserves links to the past while revitalizing our constitutional tradition to fit a dynamic, evolving society. But while Siegel may not emphasize her normative agenda, she most assuredly has one. There is more in this lecture than a description of process, more than an argument about the inevitable ways in which the views of courts and judges are shaped by the evolving understandings of the societies in which the judges also live. Siegel wants us to believe that this process is desirable, that the making and reshaping of law through social and political movements is vital in

3. James E. Fleming, Judicial Review Without Judicial Supremacy: Taking the Constitution Seriously Outside the Courts, 73 Fordham L. Rev. 1377 (2005); see also James E. Fleming, The Constitution Outside the Courts, 86 CoRnelL L. REV. 215 (2000).

4. See Reva B. Siegel, Text in Contest: Gender and the Constitution From a Social Movement Perspective, 150 U. PA. L. REv. 297 (2001); Robert C. Post \& Reva B. Siegel, Protecting the Constitution From the People: Juricentric Restrictions on Section Five Power, 78 IND. L.J. 1 (2003); Robert C. Post \& Reva B. Siegel, Equal Protection By Law: Federal Antidiscrimination Legislation After Morrison and Kimel, 110 YALE L.J. 441 (2000); Robert C. Post \& Reva B. Siegel, Legislative Constitutionalism and Section Five Power: Policentric Interpretation of the Family and Medical Leave Act, 112 YALE L.J. 1943 (2003).

5. For a review of this literature, see Larry D. Kramer, Popular Constitutionalism, circa 2004, 92 Calif. L. Rev. 959 (2004). 
sustaining the authority of the Constitution as law and in perpetuating the allegiance of Americans to our living constitutional tradition.

ls she persuasive? The role of a commentator is generally supposed to be as critic. We are expected to take issue with the author, to point out weaknesses, to challenge basic propositions, and the like. That might not be a formal requirement, but it is what audiences expect and what most commentators do. Not this one, I'm afraid, at least not with this paper. Because I could not agree more. I find Siegel's argument and analysis utterly persuasive. ${ }^{6}$ Her lecture makes a substantial contribution to a reshaping of constitutional discourse that may still be just beginning, that may still be somewhat on the fringes, but that will (I believe) inevitably become the new center of academic work in constitutional theory.

Rather than criticize, I want to offer some comments meant to highlight certain aspects of Siegel's argument that are muted or obscure, or that were not her central focus. Hence, I will begin with an observation, move on to identify certain assumptions that are necessary to make Siegel's argument work, add a couple of cautions we should keep in mind as we ruminate about her points, and conclude with a normative point of my owna place where Siegel's argument intersects and strengthens claims I have made in my own work.

\section{I}

\section{An Observation}

Consider Siegel's account of the ongoing process of constitutional development. "Constitutional culture," she says, "invites members of the polity to contest reigning constitutional understandings under semantic constraints that encourage claimants to translate challenges to the constitutional order into the language of the constitutional order, and that subject dispute to the judgment of the extended constitutional community."?

"Internalization" of this constitutional culture's process, she continues, "enables members of the polity to contest officially pronounced constitutional meanings, to propose new understandings for official recognition, and to defend those newly pronounced views." 8 Our

6. Actually, I do have one small but strongly felt criticism. I wish Siegel would banish the word "jurisgenesis" from her text. I do not mean to be a curmudgeon. I know where the word came from and why she uses it, and I appreciate what Robert Cover had to offer in Nomos and Narrative as much as anyone. See Robert M. Cover, The Supreme Court, 1982 Term - Foreword: Nomos and Narrative, 97 Harv. L. REv. 4 (1983). It was, nevertheless, a dreadful neologism when Cover coined it, grating on the ear and eye. And time has not improved the term (or the rest of its associated vocabularyjurispathic, juriscentric, etc.).

7. Reva B. Siegel, Constitutional Culture, Social Conflict and Constitutional Change: The Case of the de facto ERA, 94 CALIF. L. REV. 1323, 1350 (2006).

8. Id. at 1351 
constitutional culture, she concludes, can best be described "as practice of argument."

What struck me as I read this was how much it resembles descriptions of the seventeenth- and eighteenth-century British constitution-by which I mean the constitution of colonial America, the constitution Americans thought they were defending when they declared independence. There was a time when historians derided the notion that colonial Americans were serious in accusing England of violating their constitutional rights, as opposed to making such claims as a pretext for cruder, more material motivations. And this despite the fact that anxiety about constitutional authority pervaded the Americans' rhetoric in the decade leading up to the Revolution. But because the British customary constitution was not a matter routinely or specially addressed by judges, historians dismissed it as a system of "ethics,"10 something best understood as "a kind of moral inhibition or conscience existing in the minds of legislators and others." 11 This demotion, in turn, fit neatly with an assumption made by most lawyers and legal scholars that American constitutionalism began with the Revolution and the writing of state constitutions in 1776.

That narrow conception of constitutionalism in the eighteenth century has only recently begun to change as legal historians such as Barbara Black, Jack Greene, John Reid, and others have begun to recover the constitutional tradition of colonial America. ${ }^{12}$ This is neither the time nor the place to restate their findings in detail. Suffice it to say that, like Siegel, they argue that constitutionalism on both sides of the Atlantic relied on a culture in which public officials, community leaders, and ordinary citizens believed in a distinction between law and politics, shared a set of conventions about how to argue within each domain, and took seriously the role difference thus produced. Participants in this culture understood the distinction between fundamental law and mere politics and responded to different arguments in each setting, giving the community at large a credible interpretive voice when it came to the constitution. Problems of constitutional interpretation were thought of as "legal" problems, but also as problems that could be authoritatively addressed and settled only in and by the community. Thus, in language strikingly parallel to Siegel's, John Reid

9. Id.

10. J. W. Gough, Fundamental Law in English Constitutional History 206 (1985).

11. Gordon S. Wood, Judicial Review in the Era of the Founding, in 1s THE Supreme CourT the Guardian of the Constitution? 153, 160 (Robert A. Licht ed., 1993).

12. See Barbara A. Black, The Constitution of Empire: The Case for the Colonists, 124 U. PA. L. Rev. 1157 (1976); Jack P. Greene, Peripheries and Center: Constitutional Developments in the Extended Polities of the British Empire and the United States (1986); John Phillip Reid, Constitutional History of the AmErican Revolution (1986-1993). 
describes British constitutional culture as ultimately reflecting "whatever could be plausibly argued and forcibly maintained." 13

The similarity between Siegel's description and these historians' descriptions of colonial society is interesting and significant for a number of reasons. First, it helps refute the too-easy assumption, made by doubters of an argument like Siegel's, that there cannot be a constitutional culture that is both meaningful and recognizably "legal" outside the professional and formal institutions of lawyering and lawmaking. Look to our own past, and we discover that precisely such a culture has been flourishing for centuries.

Second, evidence of this earlier tradition conjoins nicely with Siegel's argument to suggest something about the role of text. There was a vibrant American constitutional culture before there was a text. Most commentators (or perhaps I should say most of the few who bother to pay attention to this tradition) assume this culture and its associated practices died once the text was written: at that point, they believe, constitutional law became textcentered and its management was entrusted to a priesthood of lawyers and judges. In fact, and quite to the contrary, the text was subsumed within this tradition of popular constitutionalism, becoming a focal point for community disputation, but not displacing or replacing popular activity as a generator of new constitutional developments.

The critical difference, if there is one, between Siegel's constitutional culture and that described by colonial historians has to do with how, or rather by whom, disputes were finally settled. In both systems, settlement ultimately depended on some kind of official action from government: an embrace of some new idea or activity that had popular support or a retreat from the effort to do something that lacked support. In the constitutional culture of colonial America and the Early Republic, however, no single agency of government could claim that it had formal authority to impose this settlement. Instead, control was secured by leaving matters to competition among the different branches and levels of government, in the belief that this would foster better public deliberation and that our system was robust enough to sustain disagreement until the community settled on a view. At that point, all the departments of government would fall into line or face the wrath of an aroused populace. Siegel's description, in contrast, still relies on official action, but, reminiscent of her colleague Bruce Ackerman, ${ }^{14}$ seeins to contemplate that a new constitutional regime requires either the formal ratification of an amendment or the endorsement of the Court.

I make this last observation tentatively, for Siegel does not clearly take a position, and it may be something she will eventually clarify.

13. John Phillip Reid, In a Defensive Rage: The Uses of the Mob, the Justification in Law, and the Coming of the American Revolution, 49 N.Y.U. L. REv. 1043, 1087 (1974).

14. Bruce Ackerman, We the People: Foundations (1991). 
Certainly the Court played this role in the case of the failed Equal Rights Amendment (ERA) (a point to which I will return in Part IV), but whether Siegel believes that this would and should always be the judiciary's role is less clear. Siegel is not explicit about what she sees as the authoritative role of different governmental institutions in sorting out the jumble of messages that movement and countermovement create.

II

\section{Some Assumptions}

I want to highlight a couple of important assumptions that are implicit in Siegel's account - to wit, the assumptions (mentioned above) that participants in social movements are capable of distinguishing between arguments that are legal in nature and those that are simply moral or reflect a sense of what would make good policy, and, moreover, that they take this distinction seriously. What makes our constitutional culture "constitutional," in other words, is first that it recognizes that there is a distinction between law and politics, between what our Constitution does or can plausibly be read to do and what we might like to do; and second that the members of this culture know, understand, and respect the distinction. This is what Siegel means when she says that the participants in social movements must "appeal to shared and uncontested understandings of the Constitution" and that such appeals represent a form of meaningful constraint. $^{15}$

The reason we need to highlight these assumptions is that they are, on the one hand, absolutely necessary to make Siegel's argument work; but, on the other hand (as I have discovered in the reactions to my own work), not many legal scholars are willing to accept them. Most believe that once we shift our gaze away from courts and the legal profession, the idea of law loses force. Politics, interest, and irrationality take over, and any willingness to let something as abstract as "the Constitution" shape one's ends or sense of the possible simply disappears. Indeed, most legal scholars believe this is true of the legal profession to a great (and, for some, a distressing) extent. And if true for lawyers and judges, whose training and professional lives have prepared them to accept the idea of law as an external constraint, how much truer must it be for unprincipled politicians and the unruly, undisciplined, uneducated masses?

This is an empirical question (obviously), and not one that can be settled in a short comment like this, if, indeed, it can be settled at all. For now, let me simply observe that anyone who has spent time studying popular constitutional movements - spent time, that is, reading the records and evidence those movements left behind-cannot help but come away

15. Siegel, supra note 7 , at 1357. 
convinced that Siegel is on to something. Not that the politicians, movement leaders, and ordinary citizens who get caught up in these movements do not mix their desires and moral values with their understanding of our constitutional tradition. Of course they do, as do judges and lawyers and, dare I say it, legal scholars. We would, in fact, have a perfectly dreadful constitutional tradition were it otherwise, one not worth preserving or protecting. But the ability to tie an argument to the Constitution is critical in constitutional politics, and the stronger or more persuasive the connection, the greater one's claim to legitimacy in public debate.

Indeed, in my experience, while ordinary citizens are obviously less sophisticated than legal professionals about how to make legal arguments, they take these arguments and the distinction between law and politics far more seriously. For professional training has long had the effect, if not the purpose, of making us cynics about law, and lawyers spend most of their professional lives proving to themselves how porous legal argument can be. The very naiveté of lay people--their lack of cxperience with formal legal argument-leads them to take the idea of law seriously and to separate it from their own views about how they might like things to be.

From this first assumption there flows a second, and this one suggests the need for a small modification in Siegel's argument. She says that our constitutional culture has built into it two constraints: first, that social movements must seek to prevail by appealing to the Constitution rather than against it; and second, that these movements must somehow tie their appeal to received traditions about the meaning of the Constitution. ${ }^{16}$

There is, however, a third constraint, implicit in and related to these first two, but nevertheless conceptually distinct. Following Siegel's nomenclature, we might call it the "forensic condition." By this I mean only that finding a purely conceptual or logical relation to contemporary understandings of our constitutional tradition may not be sufficient. Rather, in addition to substance, the forms of argument used to link a new claim to the received tradition must also be recognizably "legal" in nature.

Two caveats are in order. First, to say that a social movement must appeal by arguments that are recognizably legal in form is not to say that these arguments will satisfy a court, or even a lawyer or law professor. Public discourse seldom meets the standards of the profession. But to say this is not inconsistent with saying that an acceptable argument must reflect an understanding of the distinction between law and politics. Nor is it inconsistent with saying that the arguments made are in fact both meaningfully constrained and meaningfully "legal" in nature. Popular understandings of what constitutes a proper or persuasive legal argument may diverge from those of the profession without ceasing to be legal in the relevant sense.

16. Id. at 1352 . 
Second, there is no neat and tidy test for identifying which arguments are acceptably legal in nature and which are not. What counts as proper legal argument is uncertain and constantly shifting, even in the profession. The domain of arguments that can be made in a legal brief is large, while the boundary between forms of argument deemed proper and forms deemed improper is fuzzy and contested, and the standards for measuring legal judgments as right or wrong are uncertain. Yet while the canon of acceptable legal arguments may be eontested and constantly shifting, there is, at any given time, a relatively large and settled domain of arguments whose legitimacy is conceded. Disagreement may persist about whether one or another kind of argument ought to be legitimate, but there will be something approaching consensus about the social fact that such arguments are acceptable in existing legal discourse. There will, at the same time, be other arguments that all or virtually all actors in the system acknowledge as illegitimate.

So, for example, originalists who believe that arguments based on moral philosophy have no place in constitutional adjudication presumably would not deny that such arguments are nevertheless part of the existing legal culture; yet both the originalist and the moral philosopher would surely also agree that arguments based on, say, the physical attractiveness of a party or the amount of money that party contributed to a political campaign are unacceptable reasons for applying the law one way rather than another. And arguments based on natural law, once a staple of legal discourse, seldom appear at all anymore.

The idea here is simple and straightforward: because the constraint of constitutional culture rests on a perceived distinction between law and politics, parties must make their appeal by arguments that are legal in form as well as content, and the more obviously or acceptably legal the form of the argument, the greater its appeal. This is one reason why, as Siegel has argued elsewhere, the leaders of social movements care so deeply about the text. $^{17}$

A final point to note in connection with Siegel's argument that there are constraints built into our constitutional culture is that we should not take these constraints for granted. The near-sacred status of our Constitution, and so the need to seek change by appealing to rather than against its values, is by now a deep and well-established part of our political culture. But it was not always so, and the process by which our culture and tradition emerged rested as much on fortuity as on anyone's noble commitment to the Constitution.

Most Americans in the Early Republic had no such commitment. They had, in their lifetimes, abandoned England and the British constitution on which they had been raised and to which they had once shared a

17. See Siegel, Text in Contest, supra note 4. 
deep emotional attachment. ${ }^{18}$ Having rebelled a first time, moreover, they found it rather easy to do so again. The so-called Articles of Confederation and Perpetual Union lasted less than six years, and most state constitutions were rewritten several times before the nation was as old as I am. Separatist movements were rife all along the American frontier during the Confederation period,$^{19}$ and the United States could easily have developed a political culture like those we see in so many other nations around the world today, where governments are overthrown and constitutions abandoned with alacrity.

Some of the reasons this did not happen are explored in an insightfuI book by David J. Siemers entitled Ratifying the Republic. ${ }^{20}$ Once again, shortness of time and space preclude me from elaborating these reasons at length. Suffice it to say that the survival of our Constitution turned on luck as much as anything eIse, and we were fortunate that the various crises of the Early Republic unfolded in such a manner that opponents of the administration thought they stood a better chance of succeeding from within than by appealimg for yet another fundamental change.

III

\section{A Couple of Cautions}

We have a tendency, understandable but wrongheaded, to treat historical actors as if their intellectual framework was at all times fully worked out. If we see tensions and inconsistencies in what they say and do, we assume that the same must not have been true for them: they must simply have seen things differently than we do. Siegel notes, for example, that Americans of the Founding generation were committed simultaneously to principles of self-government and to gender inequality in the form of male heads of household. This was possible, she explains, because the "jurisdiction of each of [the nation's] constitutive commitments was carefully delimited - each principle in the constitutional tradition explained some social arrangements, and not others."21

Well, maybe. But then again, maybe not. The practices and beliefs that constitute our social and political and intellectual world are in constant flux, and we live with commitments that reflect inertia and unconsidered judgment as much as commitments that are considered or have been carefully worked out. Our social world is, as a result and at all times, shot

18. Richard L. Bushman, King and People in Provincial Massachusetts (1985); Gordon S. Wood, The Radicalism of the American Revolution 11-24 (1992).

19. Peter S. Onuf, The Origins of the Federal Republic: Jurisdictional Controversies IN THE UNITED STATES, I775-I 787 (1983) (offering an illuminating account of the problems presented by disputes over land and with the settlers and lndians).

20. David J. Siemers, Ratifying the Republic: Antifederalists and Federalists in Constitutional Time (2002).

21. Siegel, supra note 7 , at 1360. 
through with tensions and inconsistencies that remain unnoticed, or noticed only by a few to whom no one is yet listening.

The process by which this happens is familiar. Principles and practices that once were consistent may grow out-of-synch if social or political conditions change in ways that lead to the revision of one but not the other. The resulting tension can last for quite a long time before something new happens to cause large numbers of people to focus on the inconsistency or to challenge the unchanged practice or belief. The hierarchical status of men and women in households fits comfortably within the formally hierarchical political culture of a monarchy, where it was just one more instance of the natural order of things. ${ }^{22}$ The abandonment of monarchy for republicanism, which took place gradually between the seventeenth and nineteenth centuries, turned on changes that did not touch these household arrangements - not because to do so would have been illogical, but simply because events did not create such a focus. The resulting tension between the emergent principles of self-government and the continuing low status of women did not necessarily represent a carefully thought out set of commitments. Rather, it represented inertia in one domain because the radical changes taking place in another seemed unconnected to all but a few observers.

Eventually, other social developments threw this tension into sharper relief, and increasing numbers of people found it troubling. Some began a movement to transform the status of women. Others had the opposite reaction and formulated arguments to reconcile the tension without having to go so far. In this sense, arguments meant to preserve the status of women should be seen as reflecting a new idea or set of new ideas as much as the arguments to change their status. Neither position has or had priority, for there is no reason to assume the priority of practice over principle once these diverge into inconsistency.

The underlying point here is a familiar pragmatist one. ${ }^{23}$ Our social world consists of a complex web of practices and beliefs. We do our best to keep them consistent in the face of a constantly changing, constantly evolving environment. But a change in one part of the web will create inconsistencies in other parts, inconsistencies that often remain unnoticed. Once these become salient, we have a choice: we can modify our beliefs or we can modify our practices. The process Siegel describes, whereby arguments from self-government became available to women in the nineteenth century, is a textbook illustration.

22. See Robert A. Licht, Introduction, in Is the Supreme Court the Guardian of the Constitution? 4-11 (I993) (introducing Gorden S. Wood's essay cited in note 11); see also DoN Herzog, Happy Slaves: A CRITIQue of Consent Theory 40-46, 59-63 (1989).

23. See HerzoG, supra note 22 , at 22-27. 
What is it that brings these latent tensions to light? What causes arguments that at an earlier time would make no headway suddenly to become the foundation of a social movement? That I cannot answer-and in this instance not simply because I lack the time or space to do so. I honestly do not know the answer. No one does. We are all familiar with the idea of a zeitgeist; we experience it all the time. But we cannot really explain it.

I mention this only because it leads to a second caution to keep in mind when reading Siegel's text: namely, that we must be careful not to ascribe too much agency to the small group of participants who make up the organized wing of a social movement. Academics often write as if the arguments and advocacy of social activists are what actually produce change. What do we ourselves do, after all, except write in the hope that we will influence people to change how they think? And in researching history, the arguments documented in the work of movement activists often precede and chart or follow the larger developments that represent a movement's success. Plus their writings are the most easily accessible evidence. It is only natural, then, to attribute a large share of whatever change took place to their work and their persuasiveness.

By no means do I wish to suggest that social movements are unimportant. But neither is it clear just how big a role they play in actually changing people's minds, for they are themselves a product of the zeitgeist. Its most active and committed product, to be sure, but the same ineffable forces that produced a cadre of activists are operating on the rest of society as well, helping to lay the groundwork for change and getting people to begin thinking differently. In reading Siegel's paper, I thought back to my own experience of feminism, growing up in the early 1970s. By the time I entered high school in 1972, the basic principles of gender equality seemed pretty natural and obvious. And one thing I am sure of is that this was not because I or anyone I knew was a participant in the women's movement or read its literature or anything like that. My main exposure to feminism came through parodies of bra burning in Mad Magazine. But my mother had gone back to school and started working, and the changes in our suburban neighborhood were unmistakable. No one thought it through, no one theorized it. It just came to seem right.

Again, my point is not that activists are irrelevant. Nor do I mean to suggest that social movements are all effect and not part of what causes change. I want simply to put forth a reminder that cause and effect are immensely complicated, and that the slow processes by which ideas spread and become influential are Iittle understood. Organized movements are plainly important. But we must be careful not to give too much agency or self-conscious control to the dialectical argument between activists on both sides of a movement. They reflect as much as they create, and the 
compromise positions that eventually prevail may simply represent their inevitable retreat to a place where the rest of us have already settled or would have settled in our inchoate, inarticulate fashion.

\section{IV}

\section{A Normative Point}

Recall a point I mentioned above, that the Founding generation's vision of constitutionalism rested on competition among all the departments of government and, in theory, did not assign any one branch or department preeminence. As they theorized it, each department was responsive to the public in different ways. Each Member of the House of Representatives was tied to a relatively small constituency, but very closely; Senators were more indirectly influenced and responded to a larger constituency; the President was still further removed but responsive to the nation as a whole. Within each state, there were similar divisions and similar overlapping constituencies. And the aggregation of all these governments and departments represented the "common superior" of "the great body of the citizens of the United States" on whom every agent of government was "substantially dependent" and to whom all were ultimately accountable. ${ }^{24}$

Presupposing the same constitutional culture as Siegel, the Founders believed that where all the different levels and branches of government agreed or acquiesced in a given state action or activity, we could feel relatively confident that the action was constitutional and had genuine public support. For if not, one could depend on some set of government agents somewhere in this complex system to raise an alarm and seek to oppose it. And when departments disagreed, they were meant to fight it out by checking each other and then appealing to the public with their respective views in their respective ways. This, in turn, would produce a workable deliberative democracy in which the community would eventually back one view strongly enough to force any branches or departments that disagreed to yield.

Absolutely critical to this system was a belief that no one department spoke for the people perfectly. All were imperfect agents, and it was only through the collective response of the public to all of them that we could develop and ascertain a "popular opinion" that was reasonably informed and reasonably reflective. A multiplicity of departments was the device that made deliberative democracy possible. This is why ensuring that no one branch or department had theoretical preeminence was so important. For anything else would tip the scales toward one imperfect agent when in fact none could purport to speak for the people authoritatively, and it was

24. James Madison, The Federalist No. 46, in THE Federalist 315-16 (Jacob E. Cooke ed., 196I). 
only through full and free competition among all of them that we could secure true popular government.

Siegel's story about the failed ERA-including the fact that it was ultimately "enacted" through judicial decision making-fits this model perfectly. We are used to thinking of the Court as the unresponsive branch, the branch whose actions are least democratic, giving rise to the so-called countermajoritarian difficulty. Conversely, we are used to thinking of Article $\mathrm{V}$ as the best means for popular expression on constitutional matters, the device that unimpeachably reflects the most legitimate expression of the people's voice. Hence, Siegel opens her lecture with what, in these modern terms, looks like a genuine puzzle: if "the people" had declined to adopt the ERA through Article $V$ processes, how do we explain the absence of any strong reaction to judicial decisions effectively adopting the failed amendment by clever interpretation of the existing text? And how were the Court's decisions legitimate?

Explaining the lack of public reaction is, as Siegel observes, easy. Where the ERA appeared and could easily be portrayed as loaded with radical implications, the Court's early decisions were modest and unthreatening. Mostly, the Justices just cleared the books of old laws that no one much cared about-laws that conferred modest special benefits on widows or modest liabilities on widowers and the like. The most significant early decision, Craig v. Boren, ${ }^{25}$ extended a benefit to males, and in the decision with the greatest potential consequences, Geduldig v. Aiello, ${ }^{26}$ the Justices permitted discrimination based on pregnancy. The Court's baby steps had quite broad, if also quite passive, public support; and unlike the capacious text of the ERA, judicial action did not necessarily lead to the parade of horribles thatoopponents of women's rights could argue would quickly follow enactment of the proposed amendment.

From one perspective, Siegel is exactly right that the Court's moderation was produced by and reflected in the movement/countermovement dialectic that is the subject of her talk. But from another, we can also see it as the Founders' vision of departmentalism in action. For Article V is no more perfect a representation of popular views than any other part of the Constitution, and this is especially true for a failed Article V movement. After all, defeating a proposed amendment, like defeating proposed legislation, may reflect a variety of failures in the democratic process. If we think of Article $\mathrm{V}$ as just another imperfect means for collecting popular opinion, just another part of the proverbial elephant of popular sovereignty (so to speak), the Court's gambit can be seen as a wholly legitimate part of the process, and public acceptance of its decisions shows the Founders' system operating perfectly.

25. 429 U.S. 190 (1976).

26. 417 U.S. 484 (1974). 
Seen this way, the lesson of the failed ERA underscores the wisdom and workability of the Founders' original vision, including the idea that no one source of official action can ever claim to be "the" authoritative voice of the people. Just as the failed Article $\mathrm{V}$ amendment did not require the Court to abandon constitutional protection for sex, so too the Court's own pretensions to supremacy over the other branches must be rejected. All the available devices provided in our Constitution for seeking government action are equally available to those who support such action. It ain't over 'till it's over, and the final arbiter of whether a given action is constitutional is the public itself. Public adoption, in the meantime, is a product of public acceptance, as measured by the inability of proponents or opponents to gain political traction anywhere in the system to undo what has been done.

I have argued elsewhere that this understanding of separation of powers renders the Supreme Court's pretensions to judicial supremacy deeply troubling. ${ }^{27}$ In her conclusion, Siegel seems to suggest that we need not worry much about this: inasmuch as the ability of judges authoritatively to pronounce constitutional law will always be limited by the willingness of the public to accept what they pronounce, claims of supremacy are ultimately futile and unimportant. Other commentators have taken a similar position. $^{28}$

Yet this seems to me too quietist, for it overlooks the way in which public acceptance (or not) is itself shaped by public views as to the proper locus of authority. It is undoubtedly true that no matter what we say about the authority of judges to interpret, there is a point too far: no matter how widely the public accepts the idea of judicial supremacy, there will be limits as to what the Court can get away with. Yet it is equally trae that where those limits are located, what forms public resistance will take, and what will emerge from such resistance are critically shaped by public beliefs about who is supposed to have what authority. Judicial supremacy is an intellectual construct whose whole function and effect is to forestall popular constitutionalism and to extend how far courts can go before triggering a popular reaction. As such, it pervades the whole edifice of constitutional law, giving the justices freedom not just at the outer edges but also in areas that are not hugely controversial. Which is why Siegel should care about it, For precisely because the constitutional culture she describes is normatively attractive and historically beneficial, we should be careful not to diminish or distort it with a doctrine that makes one of the people's agents so

27. See larry D. Kramer, The People Themselves: Popular Constitutionalism and Judiclal ReviEw 227-53 (2004).

28. See Barry Friedman \& Anna Harvey, Electing the Supreme Court, 78 IND. L.J. 123 (2003); Gregory A. Caldeira \& James L. Gibson, The Etiology of Public Support for the Supreme Court, 36 AM. J. Pol. SCI. 635, 660 (1992). 
much more important than the others and that, by virtue of its importance, drains our constitutional culture of its vitality. 
